\title{
Comparison of the Influence of Trypsin on the Number of Colonies Lactobacillus spp. on the Soy Milk and Cow's Milk Medium
}

\author{
Eka Noneng Nawangsih* \\ Department of Microbiology, Faculty of Medicine \\ Universitas Jenderal Achmad Yani \\ Cimahi, Indonesia \\ *eka.noneng@lecture.unjani.ac.id
}

\author{
Ana Mariana \\ Medical Education Program, Faculty of Medicine \\ Universitas Jenderal Achmad Yani \\ Cimahi, Indonesia
}

\author{
Teja Koswara \\ Department of Pathology of Anatomy, Faculty of Medicine \\ Universitas Jenderal Achmad Yani \\ Cimahi, Indonesia
}

\begin{abstract}
Soy milk has high carbohydrate levels, so soy milk can be used as an alternative medium for the growth of Lactobacillus spp. In addition, in vivo, to be able to play an optimal role, Lactobacillus spp. must be able to survive the influence of enzymes in the digestive tract, including the trypsin enzyme. This research is an experimental laboratory that aims to compare the effect of trypsin addition on the number of Lactobacillus spp colonies using the TPC (Total Plate Count) method on soy milk and cow milk media. There are four treatment groups namely soy milk and cow milk with and without the addition of trypsin enzymes, each with 3 repetitions. Calculation of the number of colonies was carried out at the 36th hour. Data were analysed statistically using the t-independent test. The results showed that the average number of colonies of Lactobacillus spp. in soy milk is higher than cow milk, with or without the addition of trypsin. Amount of bacterial colony in the medium of soy milk is $2.5 \times 1018 \mathrm{CFU} / \mathrm{ml}$, while in cow milk $4.5 \mathrm{x}$ $1012 \mathrm{CFU} / \mathrm{ml}$. The percentage average of Lactobacillus spp mortality in soy milk is lower $(\mathbf{5 4 . 6 4 \% )}$ ) than cow milk $\mathbf{( 7 3 . 0 4 \% )}$. There was a significant difference between the percentage of Lactobacillus spp deaths. in the media of soy milk and cow milk with $p$-value $=0.00(p<0.05)$. The conclusion of this study shows that soymilk media is better at growing Lactobacillus spp. and more resistant to trypsin enzymes when compared to cow milk.
\end{abstract}

Keywords—lactobacillus spp., soy milk, cow milk, trypsin

\section{INTRODUCTION}

The growth media of probiotic bacteria circulating in society at this time is dominated by cow's milk [1]. The use of cow's milk as a medium of growth of probiotic bacteria has several drawbacks, the carbohydrate content is only $47 \%$, and the fat content is quite high, which is $33 \%$ [2]. Based on this, alternative media is needed for the growth of probiotic bacteria.
One alternative growth medium that can be used is soy milk. Soy milk has several advantages compared to cow's milk, which has a very high carbohydrate content: $62.9 \%$, and the fat content is low: $1.2 \%$. High carbohydrate levels in soy milk can be used as a good growth medium for Lactobacillus spp. [3,4]. In addition, there are other benefits owned by soy milk that is not owned by cow's milk that contains soybean trypsin inhibitors (SBTI) that can inactivate trypsin [5]

One of the requirements of probiotics is the resistance to living in the gastrointestinal tract. Thus, Lactobacillus must be able to survive in the gastrointestinal tract and maintain its standard amount in the intestines by $10^{8}$ colony forming units/mL $(\mathrm{CFU} / \mathrm{ml})$ in order to play an optimal role [6,7]. One of the substances that can inhibit the growth of probiotic bacteria is digestive enzymes. Among digestive enzymes there is a proteolytic enzyme, which is an enzyme that is able to break down proteins into smaller molecules [8]. Trypsin can represent a group of proteolytic enzymes. This enzyme is a protease enzyme produced by the pancreas and secreted into the duodenum. This enzyme hydrolyses proteins into peptides. The concentration of trypsin in the body is $0.5-1 \%$ [9]. Need a growth medium that can support carbon needs and that can increase the resistance of probiotic bacteria to the influence of trypsin in order to maintain optimal amounts until it reaches the intestines. This study aims to calculate the number of colonies and the percentage of lactobacillus spp. deaths in soymilk media, compared to cow's milk media.

\section{METHODS}

The material in this study consisted of trypsin $(15000 \mathrm{U} / \mathrm{ml})$ in $0.05 \mathrm{M}$ buffer Tris $\mathrm{HCl} \mathrm{pH} \mathrm{8,} \mathrm{deMan} \mathrm{Rogosa} \mathrm{Sharp} \mathrm{Agar}$ (MRSA) and test bacteria, namely Lactobacillus spp. from the 
Microbiology Laboratory of the Faculty of Medicine, Jenderal Achmad Yani University.

This research is an experimental laboratory research with posttest-only control research design. The study used a complete randomized design (RAL) with 3 repetitions in each treatment group. Number of lactobacillus spp. colonies. calculated using the total plate count method. The data obtained was analysed with a t-independent test. In this study there were 4 treatment groups, namely:

- Group 1: Lactobacillus spp. culture without the addition of trypsin enzyme in soymilk medium.

- Group 2: Lactobacillus spp. culture with the addition of trypsin enzyme $1 \%$ in soymilk medium.

- Group 3: lactobacillus spp. culture of the addition of the enzyme trypsin in the milk media of cows.

- Group 4: Lactobacillus spp. culture the addition of trypsin enzyme $1 \%$ in cow's milk media.

\section{A. Lactobacillus spp. Culture Manufacturing}

Lactobacillus spp. are mixed into a solution $\mathrm{NaCl} 0.9 \%$ sterile until obtained turbidity in accordance with McFarland standard $0.5\left(10^{8} \mathrm{CFU} / \mathrm{ml}\right.$ bacteria) $[10]$.

\section{B. Lactobacillus spp. Culture on Medium Soy Milk and Cow's Milk Without and With the Addition of Tripsin Concentration $1 \%$}

Inoculation $1 \mathrm{ml}$ Lactobacillus spp. media into two test reaction tubes containing $9 \mathrm{ml}$ of soy milk and two reaction tubes containing $9 \mathrm{ml}$ of cow's milk. After that, prepare trypsin (15000 U/ml) inside $0.05 \mathrm{M}$ Tris buffer $\mathrm{HCl} \mathrm{pH} 8$ with a concentration of $1 \%$. Trypsin is added to group 2 and group 4 . Each reaction tube is then heated in a $40^{\circ} \mathrm{C}$ water heater for 2 seconds while being shaken gently until the trypsin dissolves and compacted. The solution is incubated at a temperature of $37^{\circ} \mathrm{C}$ for 10 minutes. After that, the solution is diluted with $\mathrm{NaCl} 0.9 \%$ sterile until it reaches a dilution of $10^{-10}$. The dilution of solution is then transferred into a petri dish. At each dilution, 12 to $15 \mathrm{ml}$ of sterile MRS-A is added at $45^{\circ} \mathrm{C} \pm 1{ }^{\circ} \mathrm{C}$, then homogenized until compacted. This is the first layer. After that made a second layer by adding $5 \mathrm{ml}$ MRS-A until compacted. This was done three repetitions in each experimental group. Incubation of petri dish at $37^{\circ} \mathrm{C}$ for 24 hours. Then after 24 hours, the number of colonies is calculated using the Total Plate Count (TPC) method [11].

\section{Calculation of the Number of Colonies by TPC Method}

Calculation of the number of bacterial colonies, using the TPC method. Selected petri dish from each petri dish showing the number of colonies between 25-250 colonies using the colony counter tool [11].

\section{RESULTS AND DISCUSSION}

A. The Total Number of Lactobacillus spp. Colonies in Soy Milk and Cow's Milk Media with/without Tripsin Addition Concentration 1\% Incubated for 36 Hours

The calculation of the number of bacterial colonies in this study was conducted using dilution techniques with dilution from $10^{7}$ to $10^{16} \mathrm{CFU} / \mathrm{ml}$, then calculated by TPC method. The results of the observations calculated the number of colonies of lactobacillus spp. bacteria. On the medium of soy milk and cow's milk without and with the addition of trypsin seen in Table 1.

TABLE I.

NUMBER OF BACTERIAL COLONIES OF LACTOBACILLUS SPP. ON THE MEDIUM OF SOY MILK AND COW'S MILK

\begin{tabular}{|l|l|l|}
\hline \multirow{2}{*}{ Dilution } & \multicolumn{2}{c|}{ Colonies number } \\
\cline { 2 - 3 } & Soy milk & Cow's milk \\
\hline $10^{7}$ & TMTC & 250 \\
\hline $10^{8}$ & TMTC & 250 \\
\hline $10^{9}$ & TMTC & 173,3 \\
\hline $10^{10}$ & TMTC & 108 \\
\hline $10^{11}$ & TMTC & 45,3 \\
\hline $10^{12}$ & TMTC & 22,3 \\
\hline $10^{13}$ & TMTC & 22 \\
\hline $10^{14}$ & TMTC & 20 \\
\hline $10^{15}$ & TMTC & 18,5 \\
\hline $10^{16}$ & 250 & 8,3 \\
\hline \\
Description: TMTC: too much to count (>250 colonies) \\
Number of colonies that can be counted : $25-250$ colonies
\end{tabular}

Based on table 1, the number of bacterial colonies of Lactobacillus spp. on the medium of soy milk, more than cow's milk. The number of colonies in soymilk media is $2.5 \times 10^{18}$ $\mathrm{CFU} / \mathrm{ml}$, while in cow's milk $4.5 \times 10^{12} \mathrm{CFU} / \mathrm{ml}$. The results of this study show that soy milk is a good substrate for the growth of Lactobacillus spp. This bacterium can assimilate oligosaccharides (prebiotics) that are abundant in soy milk as an energy source. With the help of the enzyme b-galactosidase growth and activity of stimulated bacteria [12]. In addition to be fermented by lactobacillus spp. bacteria. Prebiotic ingredients will also produce short-chain fatty acids that can be used as energy sources [13] In addition, soy milk contains the main carbon sources of fructose and sucrose, in contrast to cow's milk, which has only the main carbon source of lactose alone [14] The other side, probiotic bacteria Lactobacillus spp. less effective at fermenting lactose in cow's milk [15].

Based on the theory also states that soy milk contains Soybean Trypsin Inhibitor (SBTI) which is a trypsin inhibitor contained in soybeans. Soybean trypsin inhibitors can inhibit the action of trypsin by bonding to the reactive protease site on trypsin which will form a single chain of polypeptides on disulfide bonds [16]

\section{B. Percentage of Lactobacillus spp. on The Medium of Cow's Milk and Soy Milk}

Here is the percentage of lactobacillus spp. deaths. On the medium of cow's milk and soy milk. 
TABLE II. PERCENTAGE OF LACTOBACILLUS SPP. DEATHS ON THE MEDIUM OF COW'S MILK AND SOY MILK

\begin{tabular}{|l|l|l|}
\hline \multirow{2}{*}{ Dilution } & \multicolumn{2}{|c|}{ Percentage of lactobacillus spp. deaths } \\
\cline { 2 - 3 } & \multicolumn{1}{|c|}{ Cow's milk } & Soy milk \\
\hline $10^{7}$ & $0 \%$ & $0 \%$ \\
\hline $10^{8}$ & $0 \%$ & $0 \%$ \\
\hline $10^{9}$ & $76,5 \%$ & $0 \%$ \\
\hline $10^{10}$ & $87,3 \%$ & $0 \%$ \\
\hline $10^{11}$ & $82,3 \%$ & 79,3 \\
\hline $10^{12}$ & $94,1 \%$ & $92,2 \%$ \\
\hline $10^{13}$ & $95,4 \%$ & $92,6 \%$ \\
\hline $10^{14}$ & $96,5 \%$ & $93,2 \%$ \\
\hline $10^{15}$ & $98,3 \%$ & $94,1 \%$ \\
\hline $10^{16}$ & $100 \%$ & $95 \%$ \\
\hline
\end{tabular}

Based on Table 2, the average percentage of Lactobacillus spp. deaths in soy milk is lower $(54.64 \%)$ than cow's milk (73.04\%). Trypsin can inhibit bacterial growth because cell surface proteins that have molecular weight 250 -k are highly sensitive to the action of trypsin. Trypsin can eliminate $250-\mathrm{k}$ of cell surface proteins that can play a direct role in bacterial cell growth. Soy milk contains Soybean Trypsin Inhibitors (SBTI) that can inhibit trypsin by bonding to reactive site protease on trypsin that forms a single chain of polypeptides in disulfide bonds $[17,18]$.

In addition, the content of soy milk is high in carbohydrates (especially sucrose and fructose) when compared to cow's milk which has lower carbohydrate levels. Soy milk has oligosaccharides (prebiotics) as an energy source that stimulates the growth and activity of Lactobacillus spp. [19].

\section{Analysis of Lactobacillus spp. Mortality Data on Cow's Milk and Soy Milk Media}

To determine a significant difference in the percentage of deaths in the media group of soy milk and cow's milk, a tindependent test was conducted. The results of the analysis can be seen in Table 3 .

TABLE III. RESULTS OF ANALYSIS OF LACTOBACILLUS SPP. DEATH Percentage Data on the Medium OF Cow's Milk AND Soy MilK

\begin{tabular}{|l|c|c|l|l|}
\hline Percentage of death & $\mathbf{N}$ & Mean & Sig. Uji Normality & \multirow{2}{*}{ Sig. $\boldsymbol{t}$-Test } \\
\cline { 1 - 4 } Soy milk & 10 & $54,64 \%$ & 1,000 & \multirow{2}{*}{0.00} \\
\hline Cow's milk & 10 & $73,04 \%$ & 1,000 & \\
\hline
\end{tabular}

In table 3 , the $\mathrm{T}$-independent test result was $\mathrm{p}<0.05$, indicating that there was a significant difference between the percentage of Lactobacillus spp. deaths. On the medium of cow's milk and soy milk. This suggests that Lactobacillus spp. in soymilk media is more resistant to exposure to the enzyme trypsin when compared to cow's milk media. Therefore, soy milk can be used as an alternative probiotic medium.

\section{CONCLUSIONS}

- Average number of lactobacillus spp. colonies. with/without trypsin in soymilk media more $\left(2.5 \times 10^{15} \mathrm{CFU} / \mathrm{ml}\right)$ when compared to cow's milk media $\left(4.7 \times 10^{10} \mathrm{CFU} / \mathrm{ml}\right)$

- Average percentage of Lactobacillus spp. deaths in soymilk media is less $(54.64 \%)$ when compared to cow's milk media $(73.04 \%)$

- There is a significant difference between the percentage of Lactobacillus spp. deaths in cow's milk and soy milk $(\mathrm{p}<0.05)$. Soymilk media is better at growing Lactobacillus spp. and more resistant to trypsin when compared to cow's milk.

\section{ACKNOWLEDGMENTS}

Thank you to laboratory microbiology staff and the research institute and community service Jenderal Achmad Yani University for the support of research funding provided

\section{REFERENCES}

[1] G.T. Rijkers, W.M. De Vos, R.J. Brummer, L. Morelli, G. Corthier and P. Marteau, "Health benefits and health claims of probiotics: bridging science and marketing," British Journal of Nutrition, vol. 106, no. (9), pp. 1291-1296, 2011.

[2] R.C. Chandan and A. Kilara, Dairy ingredients for food processing. New Jersey: John Wiley \& Sons.

[3] G.T. Rijkers, S. Bengmark, P. Enck, D. Haller, U. Herz, M. Kalliomaki and J.M. Antoine, "Guidance for substantiating the evidence for beneficial effects of probiotics: current status and recommendations for future research," The Journal of nutrition, vol. 140, no. (3), pp. 671S676S, 2010

[4] E. Chukeatirote, "Potential use of probiotics," Songklanakarin J Sci Technol, vol. 25, no. (2), pp. 275-282, 2003.

[5] K. Liu, Soybeans: chemistry, technology, and utilization. Berlin: Springer, 2012.

[6] S. Plessas, A. Alexopoulos, C. Voidarou, E. Stavropoulou and E. Bezirtzoglou, "Microbial ecology and quality assurance in food fermentation systems. The case of kefir grains application," Anaerobe, vol. 17, no. (6), pp. 483-485, 2011.

[7] Food and Agriculture Organization of the United Nation and World Healh Organization (FAO), Guidlines for the evaluation of probiotics in food. Canada: FAO, 2006.

[8] K.Y. Lee and T.R. Heo, "Survival of Bifidobacterium longum immobilized in calcium alginate beads in simulated gastric juices and bile salt solution," Applied and environmental microbiology, vol. 66, no. (2), pp. 869-873, 2000.

[9] Trypsin: Definition, Function \& Mechanism of Action, Retrieved from https://study.com/academy/lesson/trypsin-definition-functionmechanism-of-action.html., 2017.

[10] C.R. Mahon, D.C. Lehman and G. Manuselis, Textbook of diagnostic microbiology-e-book. Amsterdam: Elsevier Health Sciences, 2018.

[11] J.G. Cappuccino and N. Sherman, Microbiology: a laboratory manual. London: Pearson Education, 2005.

[12] B.P. Lamsal, "Production, health aspects and potential food uses of dairy prebiotic galactooligosaccharides," Journal of the Science of Food and Agriculture, vol. 92, no. (10), pp. 2020-2028, 2012.

[13] J.G. Endres, Soy protein products: characteristics, nutritional aspects, and utilization. Illinois: The American Oil Chemists Society, 2001.

[14] O.E. Mäkinen, V. Wanhalinna, E. Zannini and E.K. Arendt, "Foods for special dietary needs: Non-dairy plant-based milk substitutes and 
fermented dairy-type products," Critical reviews in food science and nutrition, vol. 56, no. (3), pp. 339-349, 2016.

[15] S.E. Gilliland, L. Morelli and G. Reid, Health and nutritional properties of probiotics in food including powder milk with live lactic acid bacteria," Joint FAO/WHO expert consultation. Cordoba, Argentina, 2001.

[16] S. Avilés-Gaxiola, C. Chuck-Hernández and S.O. Serna Saldivar, "Inactivation methods of trypsin inhibitor in legumes: a review," Journal of food science, vol. 83, no. (1), pp. 17-29, 2018.

[17] E.R. Coscueta, M.E. Pintado, G.A. Picó, G. Knobel, C.E. Boschetti, L.P. Malpiedi and B.B. Nerli, "Continuous method to determine the trypsin inhibitor activity in soybean flour," Food chemistry, vol. 214, pp. 156$161,2017$.

[18] S. Klomklao, S. Benjakul, H. Kishimura and M. Chaijan, "Extraction, purification and properties of trypsin inhibitor from Thai mung bean (Vigna radiata (L.) R. Wilczek)," Food chemistry, vol. 129, no. (4), pp. 1348-1354, 2011.

[19] X. Shi, J. Li, S. Wang, L. Zhang, L. Qiu, T. Han and S. Guo, "Flavor characteristic analysis of soymilk prepared by different soybean cultivars and establishment of evaluation method of soybean cultivars suitable for soymilk processing," Food Chemistry, vol. 185, pp. 422429, 2015. 